\title{
Therapeutic efficacy of different Hemodialysis prescriptions in canine azotemia
}

\author{
Ekta Atul Thakkar ${ }^{1}$, and Rajiv V. Gaikwad ${ }^{1,2}$
}

1. Department of Veterinary Clinical Medicine, Ethics and Jurisprudence, Bombay Veterinary College, Parel, Mumbai, Maharashtra, India; 2. Department of Veterinary Clinical Medicine, Ethics and Jurisprudence and I/C Department of Veterinary Nuclear Medicine, Bombay Veterinary College, Parel, Mumbai, Maharashtra, India.

Corresponding author: Rajiv V. Gaikwad, email: drrvg2001@gmail.com, EAT: ektaathakkar@gmail.com Received: 29-07-2014, Revised: 05-11-2014, Accepted: 20-11-2014, Published online: 29-12-2014

doi: 10.14202/vetworld.2014.1150-1156. How to cite this article: Thakkar EA, Gaikwad RV (2014) Therapeutic efficacy of different Hemodialysis prescriptions in canine azotemia, Veterinary World 7(12): 1150-1156.

\begin{abstract}
Aim: The aim was to determine therapeutic efficacy of different Hemodialysis prescriptions in canine azotemia.

Materials and Methods: Patients $(n=9)$ with acute onset of renal dysfunction or chronic patients with superimposed acute factor (component) or patients with known chronic nature of the disease were dialyzed with Fresenius 4008S hemodialysis machine after jugular catheterization. Patients were randomly divided into two groups, one group ( $\mathrm{n}=3$ ) was dialyzed every day and second $(n=4)$ was dialyzed on alternate days. The patients were evaluated for following parameters to compare the efficacy of the dialysis prescription: Urea reduction ratio (URR), creatinine reduction ratio (CRR), Kt/V, time averaged concentration of urea (TAC urea).
\end{abstract}

Result and Discussion: Increasing both dialysis frequency and duration is the superior dialysis schedule. Patient dialyzed every day with total processed blood volume $1.79 \mathrm{~L} / \mathrm{Kg}$ for $4 \mathrm{~h} 26 \mathrm{~min} / \mathrm{session}$ had the lowest TAC of $36.82 \mathrm{mg} / \mathrm{dl}$, thereby was considered it as a better prescription.

Keywords: creatinine reduction ratio, hemodialysis, $\mathrm{Kt} / \mathrm{V}$, time averaged concentration of urea, urea reduction ratio.

\section{Introduction}

Clinical azotemia is amongst the most common clinical ailments encountered in dogs, which could be due to intrinsic renal insult or extra-renal factors and is manifested by involvement of gastrointestinal, cardiovascular and nervous systems, depending on the duration of exposure of these systems to the uremic toxins and in turn, to the degree of damage to the renal parenchyma. Any form of insult whether it be an acute or chronic results in the disturbance of the whole orchestra of the kidney resulting in accumulation of uremic retention solutes which is then manifested as "uremic syndrome." No collection of conventional therapies has yet been able to reproduce the efficacy of Hemodialysis procedures, with respect to the correction of cumulative biochemical, acid-base, endocrine and fluid disorders of this syndrome [1]. Delay in instituting dialysis leads to greater uremic symptomology, morbidity, and recruitment of additional organ dysfunction [2].

The rationale for dialysis therapy is that these retained solutes have concentration dependent and cumulative toxicity, which can be ameliorated through its removal by dialysis [3].

The outcome of the cases with renal dysfunction, however, depends upon the extent of renal injury, the residual kidney function and involvement of extra-renal organ systems. The cases with

Copyright: The authors. This article is an open access article licensed under the terms of the Creative Commons Attributin License (http:// creative commons.org/licenses/by/2.0) which permits unrestricted use, distribution and reproduction in any medium, provided the work is properly cited. acute kidney injury with tubular damage may take 3-4 weeks for repair and restoration of renal function [4]. However, the severity of azotemia may preclude the opportunity for kidneys to repair, and may result in mortality in the absence of the hemodialysis support. On the other hand, chronic cases may need extended extracorporeal support until resolution of uremic signs. It becomes a clinical necessity to identify an improving or deteriorating trend in the renal function, so as to facilitate the titration in the therapeutic management [5].

Renal replacement therapy comprises of Peritoneal Dialysis, continuous renal replacement therapy (CRRT) and intermittent hemodialysis (IHD). CRRT is a continuous process of slow and gradual removal of uremic toxins which continues until the kidney function returns, or the patient is stable enough for IHD [6]. It works on the principles of convection, diffusion, adsorption and ultrafiltration and best suits the needs of Acute Kidney Injury AKI patients [7].

IHD is a renal replacement modality that is defined by short, efficient hemodialysis sessions with the goal of removing uremic toxins from the blood stream. It works on the principles of diffusion and ultrafiltration. CRRT is better for the removal of middle molecular and toxins with a greater compartmental distribution.

IHD the most commonly used modality of renal replacement therapy is typically prescribed for 3 or 4 h 3 or more times per week. Recent data suggest that alternate day dialysis provides inadequate dialysis dosing in the majority of critically ill-patients. 
Urea can serve as a generic/surrogate/prototype molecule and has been used to quantify the efficacy of hemodialysis treatment, and is represented as - fractional clearance of urea distribution volume $(\mathrm{Kt} / \mathrm{V})[8,9]$.

There are different protocols practiced worldwide for the delivery of hemodialysis for chronic and acutely ill renal patients. Stable chronic kidney disease (CKD) patients on maintenance hemodialysis are prescribed hemodialysis typically for $6 \mathrm{~h}$ twice a week, $4 \mathrm{~h}$ sessions thrice a week, extended sessions on alternate days, short daily hemodialysis sessions or daily nocturnal sessions for 6-8 h. There is, however, no consensus on the dialysis prescription for the patients presented with acute kidney injury and different protocols are being evaluated for its efficacy and potential to affect the ultimate outcome [10-12].

The patients presented acutely are almost always fluid overloaded, due to the altered output and overzealous, but unsuccessful therapeutic attempts to induce diuresis. The benefit of frequent hemodialysis may result from improved control of other metabolic by-products, such as phosphate or other retained uremic solutes, more physiologic removal of solutes (yielding lower and less variable time-averaged solute concentrations), or improved control of extracellular volume excess [13].

Due to ongoing uncertainty regarding the optimal dose of hemodialysis, it is essential to compare frequent (6 times/week) or daily hemodialysis with conventional thrice-weekly hemodialysis.

Identifying the clinical need of monitoring the renal function, in patients undergoing conventional and hemodialytic treatment with different dialysis prescriptions - present research entitled "Therapeutic efficacy of different hemodialysis prescriptions in canine azotemia," was undertaken to compare efficacy of daily versus alternate-day hemodialysis.

\section{Materials and Methods}

\section{Ethical approval}

The cases included in study were clinical cases who underwerent hemodialysis as a part of their treatment, and the data obtained was included in the study. The study entitled "Therapeutic efficacy of different hemodialysis prescriptions in canine azotemia", was carried out on nine azotemic canine patients, at hemodialysis Unit, Department of Veterinary Clinical Medicine, Ethics and Jurisprudence, Bombay Veterinary College. The cases referred from outpatient department, Teaching Veterinary Clinical Complex, Department of Medicine, private practitioners and the affiliated BSDPHA hospital, were included in the study.

Nine azotemic canines exhibiting classical signs of azotemia and those refractory to conventional medical management underwent hemodialysis treatment. The patients warranting long-standing dialysis support due to the known chronic nature of the disease were also offered dialysis. Patients were then grouped randomly into two groups. First group comprised of five patients to be dialyzed every day and the second group had four azotemic canines to be dialyzed on alternate days. Two patients from the first group succumbed $24 \mathrm{~h}$ after the first session of dialysis, due to the severity of azotemia and co-morbid conditions, leaving behind three patients in first group and four in the second.

\section{Inclusion criteria}

Ailing canines with biochemical evidence of azotemia and refractory to the conventional therapy, fulfilling the following inclusion criterion were subjected to hemodialysis. Serum creatinine $\geq 4 \mathrm{mg} / \mathrm{dl}$, Clotting Time between 3 and $5 \mathrm{~min}$ and a hematocrit of $\geq 20 \%$.

\section{Evaluation of patients under study}

Patients with acute onset of renal dysfunction or chronic patients with superimposed acute factor (component) or patients with known chronic nature of the disease requiring maintenance dialysis were included in the study. Preliminary evaluation of the patient included patient's age, sex, breed, weight, duration of illness previous medical history, biochemical, hematological and blood gas evaluation, urine examination and ultrasound of abdomen and pelvis.

\section{Preliminary preparation for initiating hemodialysis treatment}

Patients after thorough evaluation were hydrated if required based on their hydration status, and then dual lumen silicon hemodialysis catheter were used for the vascular access [14]. The catheter size was selected suiting the patient requirement. For patients weighing $15 \mathrm{~kg}$ and more, catheter of size $11.5 \mathrm{~F} \times$ $24 \mathrm{~cm}$ were used, whereas for a patient weighing $8 \mathrm{~kg}$, a Dacron cuffed catheter of size $10 \mathrm{~F} \times 13 \mathrm{~cm}$ was used. The patients undergoing hemodialysis were catheterized in their right jugular vein (Figure-1).

Hemodialysis treatment necessitates: A dialysis delivery machine, extracorporeal blood circuit (blood tubings), a dialyzer (artificial kidney), dialysate solutions, a method to access the patient's central blood pool and a supply of reverse osmosis treated water (RO water) fulfilling the guidelines issued by AAMI (Figures-2 and 3).

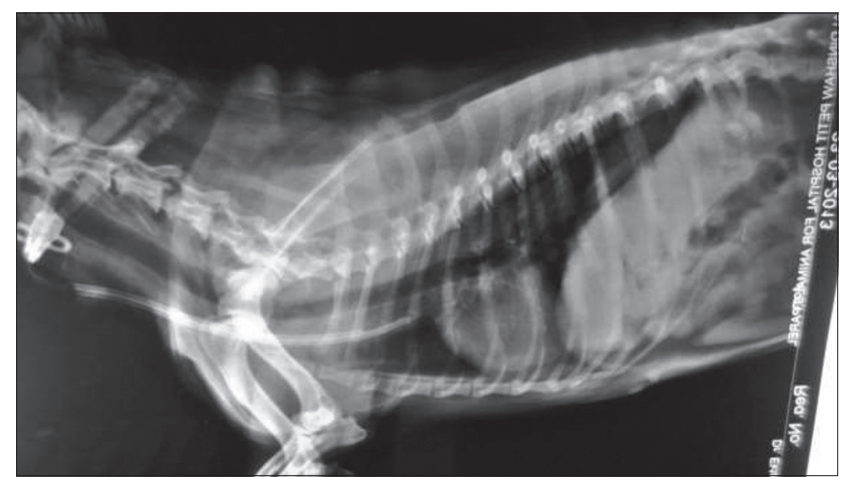

Figure-1: Radiograph showing ideal position of dacron cuffed catheter of size $10 \mathrm{~F} \times 13 \mathrm{~cm}$ catheter. 


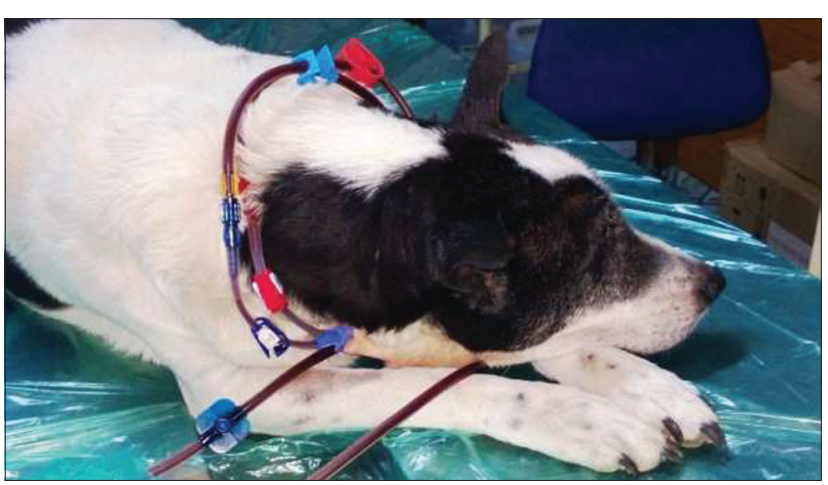

Figure-2: Pooh being dialysed.

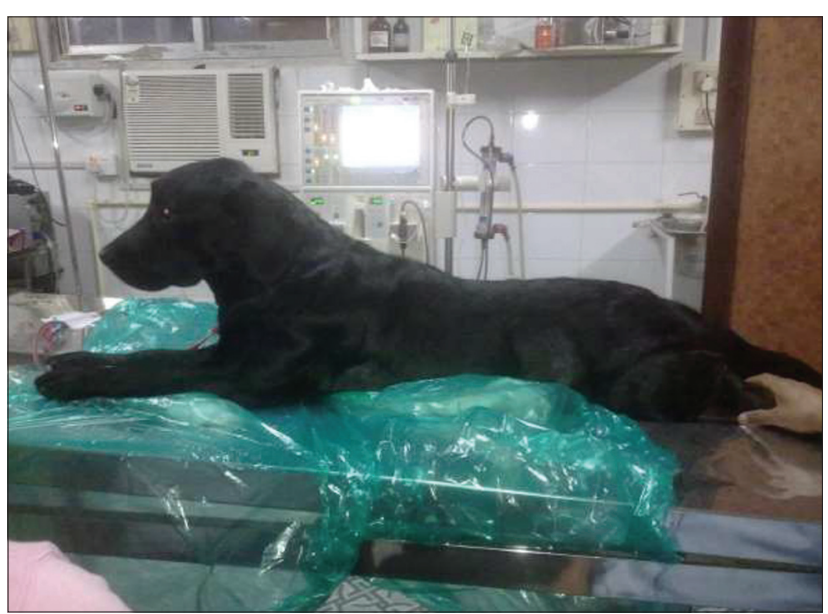

Figure-3: Jai being dialysed.

\section{Dialysis prescription}

Dialysis prescription was customized for each patient based on the presentation parameters viz. Body weight, serum blood urea nitrogen (BUN) concentration, blood pressure, volume overload, platelet counts, residual renal function, urea and creatinine build up etc. Dialyzers and blood tunings were selected based on patient's weight considering their contribution to the extracorporeal volume [15]. Temperature of the dialysate was set at $38^{\circ} \mathrm{C}-39^{\circ} \mathrm{C}$. The sodium concentration of the dialysate was adjusted $\pm 2-3 \mathrm{mEq} / \mathrm{L}$ of the patient's sodium levels, so that no drastic changes in the concentration of sodium and in turn, in the osmolality are done, which leads to either shrinkage of cells or edema with drastic changes in dialysate sodium, unless it was clinically indicated. The Dialysate flow rate was kept constant at $500 \mathrm{ml} / \mathrm{min}$ for all the cases except one patient who was dialyzed at a lower dialysate flow rate of $300 \mathrm{ml} / \mathrm{min}$ due to its low blood flow rate attributed to the prescription and low blood flow rates obtained from the patient's catheter owing to its small bore size.

Dialysis dose to be delivered was calculated based on starting or pre-dialysis BUN concentration and the post-dialysis BUN concentration. Estimation of urea reduction ratio (URR) was done per hour of treatment (hourly URR is only used for prescription, for evaluation of treatment efficacy total URR [\%] delivered per session is considered). The hourly URR was used as a guide to select an appropriate treatment time as an excessive hourly URR is more likely to cause intra-dialytic complications in patients with higher BUN than the absolute decrease in BUN over the dialysis session [16]. Initial dialysis treatments typically are less intensive (less solute removal, slower blood flow rate, smaller dialyzer surface area, and possibly shorter treatment time) than those prescribed for subsequent treatments. The clotting time was checked for every patient before initiating the dialysis. The adjustments in the heparinization were necessary for patients with altered clotting mechanisms. A heparin bolus of 40-50 IU/kg was prescribed for anticoagulation and maintenance was done @ 25-50 IU/kg/hr as a continuous rate infusion of heparinized saline [17]. The patients were evaluated for URR, creatinine reduction ratio ( $\mathrm{Cr} \mathrm{RR}), \mathrm{Kt} / \mathrm{V}$, time averaged concentration (TAC) urea to compare the efficacy of the dialysis prescription.

\section{Results and Discussion}

The mean age among nine canines presented was $8 \pm 2.72$ years, with a range of 5-13 years. All cases aged 5 years and above of which $66 \%(n=6)$ aged between 5 and 10 years and 44\% $(n=3)$ from 10 to 13 years. The average weight of the patients was $29.05 \pm 14.14 \mathrm{~kg}$ which varied from $8.4 \mathrm{~kg}$ to $46.3 \mathrm{~kg}$. The presenting complaints and clinical signs are tabulated in Table-1.

The presented azotemic canines had BUN and creatinine values ranging from $22.98 \mathrm{mg} /$ dl to $138.00 \mathrm{mg} / \mathrm{dl}$ with a mean \pm standard deviation (SD) of $95.00 \pm 25.07 \mathrm{mg} / \mathrm{dl}$ and $4.70 \mathrm{mg} / \mathrm{dl}$ to $26.10 \mathrm{mg} / \mathrm{dl}$ with a mean $\pm \mathrm{SD}$ of $14.35 \pm 7.49 \mathrm{mg} / \mathrm{dl}$ respectively. The mean partial thromboplastin time (PTT) and activated PTT values were $7.50 \mathrm{~s}$ and $10.30 \mathrm{~s}$ respectively. Anorexia and vomiting were observed in $66.60 \%$ and $100 \%$ patients respectively, whereas $55.50 \%$ had melena. $33.33 \%$ patients had cardiac involvement, and $88.88 \%$ were found to be hyperphosphatemic. Hypertension was recorded in $22.22 \%$ of patients, of which both had a cardiac pathology $[18,19]$.

The average sodium, chloride and potassium values recorded were $145 \pm 3.61(\mathrm{mEq} / \mathrm{L}), 100.67 \pm 3.00$ $(\mathrm{mEq} / \mathrm{L})$ and $4.4 \pm 1.26(\mathrm{mEq} / \mathrm{L})$ respectively thereby showing no deviation from their normal range. The hemoglobin values of the patients ranged from $7.30(\mathrm{~g} \%)$ to $11.50(\mathrm{~g} \%)$ whereas a variation of $3.30 \mu \mathrm{s} / \mathrm{cumm}$ to $5.04 \mu / \mathrm{cumm}$ and $120000 / \mu \mathrm{l}$ to $440000 / \mu 1$ was recorded in red blood cells (RBCs) and platelets respectively.

The mean \pm SD hematocrit, hemoglobin and Red blood cells of the patients were $28.51 \pm 4.21,9.34 \pm 1.42$, $4.00 \pm 0.63$ respectively. The Mean $\pm \mathrm{SD}$ of $\mathrm{WBC}$ count of seven patients was $11857.14 \pm 4095.47 / \mu 1$, a high count of $34500 / \mu \mathrm{L}$ and $42300.00 / \mu 1$. Mean \pm SD platelet count was $214000.00 \pm 104953.05 / \mu 1$. Platelet counts were in normal range except in three patient 
where thrombocytopenia was recorded with a platelet

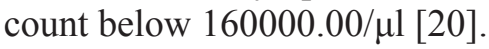

A mild normocytic normochromic anemia was observed in $(n=3)(33.33 \%)$ patients, moderate normocytic normochromic in $(\mathrm{n}=2)(22.22 \%)$ patients, whereas $(n=3)(44.44 \%)$ patients suffered from moderate hypochromic microcytic anemia. Based on the clinical examination, hemoto biochemical and ultrasound evaluation patients were classified as per IRIS guidelines [21] (Table-2). Based on the evaluation of all the presented nine azotemic canines an inference was drawn on the current status of the patients according to which four patients (44.44\%) were proven CKD

Table-1: Presenting complaint and clinical signs.

\begin{tabular}{|c|c|c|}
\hline $\begin{array}{l}\text { Patient } \\
\text { number }\end{array}$ & $\begin{array}{l}\text { Patient } \\
\text { name }\end{array}$ & $\begin{array}{l}\text { Presenting complaint and clinical } \\
\text { signs }\end{array}$ \\
\hline 1 & Jai & Vomition, anorexia, melena \\
\hline 2 & Tisha & Vomition, melena, bilateral nephroliths \\
\hline 3 & Sheeba & $\begin{array}{l}\text { Vomition, anorexia, lying prostate, } \\
\text { melena, oral ulceration LVE }\end{array}$ \\
\hline 4 & Buzo & $\begin{array}{l}\text { Vomition, decreased appetite, DCM, } \\
\text { MVI Grade III, TVI Grade II }\end{array}$ \\
\hline 5 & Pooh & Vomition, melena \\
\hline 6 & Rusty & $\begin{array}{l}\text { Vomition, anorexia, melena, anemia, } \\
\text { oral ulceration, weight loss in } 3 \text { months }\end{array}$ \\
\hline r & Alex & Vomition, anorexia \\
\hline 8 & Sonu & $\begin{array}{l}\text { Vomition, anorexia, respiratory } \\
\text { distress, DCM }\end{array}$ \\
\hline 9 & Zedan & $\begin{array}{l}\text { Vomition, anorexia, icterus, anuria, } \\
\text { pleural effusions, pleural oedema, } \\
\text { Bilateral nephromegaly }\end{array}$ \\
\hline
\end{tabular}

MVI=Mitral valve insufficiency, DCM=Dilated cardiomyopathy patients [22]. Three patients $(33.33 \%)$ namely Jai, Alex, Sonu were suspected to have a super imposed acute factor on pre-existing chronic renal injury. Two patients namely Tisha and Zedan $(22.22 \%)$ were diagnosed to suffer from AKI based on their recent onset of azotemia, among them Zedan was a typical AKI patient with anuria, hyper billirubinamia, bilateral nephromegaly and pleural effusions suspected to suffer from leptospirosis (based on the clinical and laboratory investigations). Tisha suffered from bilateral nephrolithiasis.

\section{Efficacy of different dialysis prescriptions}

Table-3 summarizes the URR, CrRR and spKt/V calculated from the pre and post values of BUN and creatinine obtained before and after dialysis in order to evaluate the dose and efficacy of hemodialysis. The URR achieved in first two sessions was as per the recommendations of wherein, first treatment was aimed at decreasing the BUN level by $25 \%-33 \%$, second by $50 \%$. For third and fourth treatment the URR delivered should be around $95 \%$. Most cats and small dogs weighing $<50 \mathrm{~kg}$ should achieve an URR approaching $95 \%$. The URR achieved in third and subsequent sessions was less than $95 \%$ as the blood flow rates were slower when compared to faster blood flow rates of $10 \mathrm{ml} / \mathrm{kg}$ as recommended by Langstan.

The foremost goal of dialysis or any efficient dialysis prescription is to maintain BUN and creatinine values within an acceptable range without an enormous difference from the normal limits. The integrated exposure to uremia toxins over time is

Table-2: Classification of cases based on IRIS guidelines.

\begin{tabular}{|c|c|c|c|c|c|}
\hline $\begin{array}{l}\text { Patient } \\
\text { number }\end{array}$ & $\begin{array}{l}\text { Patient } \\
\text { name }\end{array}$ & Creatinine & UPC & $\begin{array}{l}\text { Systolic BP } \\
(\mathbf{m m ~ H g})\end{array}$ & IRIS classification \\
\hline 1 & Jai & 12.95 & 0.30 & 130 & $\begin{array}{l}\text { CKD Stage } 4 \text {, borderline proteinuric, } \\
\text { AP } 0 \text { (after } 2 \text { weeks of dialysis) }\end{array}$ \\
\hline 2 & Tisha & 8.40 & 0.68 & 140 & $\begin{array}{l}\text { CKD Stage } 2 \text {, non proteinuric, AP } 0 \\
\text { ( } 10 \text { days post withdrawal of dialysis) }\end{array}$ \\
\hline 3 & Sheeba & 6.66 & 1.10 & 170 & CKD Stage 4 , proteinuric, AP2C \\
\hline 4 & Sonu & 26.10 & 1.14 & 130 & $*$ \\
\hline 5 & Buzo & 9.92 & 1.83 & 180 & CKD Stage 4, proteinuric, AP3C \\
\hline 6 & Pooh & 22.18 & 1.23 & 130 & CKD Stage 4 , proteinuric, APO \\
\hline 7 & Alex & 4.70 & - & 130 & CKD stage 2 , UTI, APO \\
\hline 8 & Rusty & 8.10 & 1.50 & 140 & CKD Stage 4 , proteinuric, APO \\
\hline 9 & Zedan & 20.49 & Anuric & 120 & AKI Stage 5, anuric \\
\hline
\end{tabular}

*Couldn't be classified as the dog succumbed within $24 \mathrm{~h}, \mathrm{CKD}=$ Chronic kidney disease, AP=Arterial pressure, UTI=Urinary tract Infection, AKI=Acute kidney injury, BP=Blood pressure

Table-3: Mean \pm SD values of URR, CrRR and spKt/V of five dialysis sessions.

\begin{tabular}{lccccc}
\hline $\begin{array}{l}\text { Session } \\
\text { no }\end{array}$ & \multicolumn{5}{c}{ Mean \pm SD } \\
\cline { 2 - 6 } & Blood processed L/ kg & URR (\%) & CrRR (\%) & spKt/V & Td (h) \\
\hline 1 & $0.70 \pm 0.44$ & $48.76 \pm 27.46$ & $55.84 \pm 24.64$ & $0.88 \pm 0.64$ & $2 \mathrm{~h} 52 \mathrm{~min} \pm 1.03 \mathrm{~h}$ \\
2 & $1.630 \pm 0.44$ & $73.41 \pm 13.23$ & $71.50 \pm 12.75$ & $1.454 \pm 0.58$ & $4 \mathrm{~h} \pm 53 \mathrm{~min}$ \\
3 & $2.098 \pm 0.55$ & $61.52 \pm 18.83$ & $75.87 \pm 8.31$ & $1.088 \pm 0.63$ & $4 \mathrm{~h} 40 \mathrm{~min} \pm 24.71 \mathrm{~min}$ \\
4 & $1.795 \pm 0.26$ & $60.15 \pm 31.59$ & $56.38 \pm 5.06$ & $1.11 \pm 0.89$ & $4 \mathrm{~h} 34 \mathrm{~min} \pm 48.79 \mathrm{~min}$ \\
5 & $2.26 \pm 0.06$ & $65.90 \pm 1.24$ & $60.41 \pm 5.13$ & $1.075 \pm 0.04$ & $5 \mathrm{~h} 26 \mathrm{~min} \pm 5.66 \mathrm{~min}$ \\
\hline
\end{tabular}

$\mathrm{CrRR}=$ Creatinine reduction ratio, $\mathrm{spKt} / \mathrm{V}=$ Single pool $\mathrm{Kt} / \mathrm{V}, \mathrm{TAC}$ urea $=$ Time avereged concerntration of urea, URR $=\mathrm{Urea}$ reduction ratio, $\mathrm{Td}=$ Time of dialysis, $\mathrm{SD}=$ Standard deviation 
considered a more realistic determinant of well-being and therapeutic adequacy [23]. For urea, this is expressed as the time-averaged concentration (TAC urea), which is calculated as the area under the BUN profile (curve) divided by the duration of the dialysis cycle In order to arrive at a conclusion so as to which prescription is more efficient TAC urea was calculated.

TAC urea gives an estimate of the average BUN to which patient is exposed in between two dialysis treatments. Thus the efficacy of the procedure can be determined. The mean $\pm \mathrm{SD}$ TAC urea recorded in patients dialyzed everyday was $71.77 \pm 20.07 \mathrm{mg} / \mathrm{dl}$ which was more when compared to the patients dialyzed on alternate days having a TAC urea of $54.36 \pm 20.33 \mathrm{mg} / \mathrm{dl}$ (Tables-4 and 5). The higher TAC urea obtained in Group 1 i.e. everyday day group is attributed to the more amount of blood processed 2.66 $\pm 0.96 \mathrm{~L} / \mathrm{kg}$ in Group 2 patients as compared to Group 1 wherein comparatively less volume of blood was processed $2.06 \pm 0.82 \mathrm{~L} / \mathrm{kg}$. Group 2 patients were dialyzed for longer duration i.e. $3.76 \pm 0.68 \mathrm{~h}$ as compared to shorter treatment time of Group 1 i.e., $3.26 \pm 0.84$ h. Higher amount of blood processed for more duration indeed results in better clearance of uremic toxins and therefore a lower TAC urea. The residual renal function $(\mathrm{Kr})$ also plays a role in lowering the BUN concentrations by aiding natural excretion $[24,25]$.
Table- 6 gives a summarized data of TAC urea of the patients with similar BUN values and dialyzed on different prescriptions. A lower TAC urea $36.82 \mathrm{mg} / \mathrm{dl}$ was obtained with a high volume of blood is processed for a longer duration and frequently (Figure-4) as compared to the other two

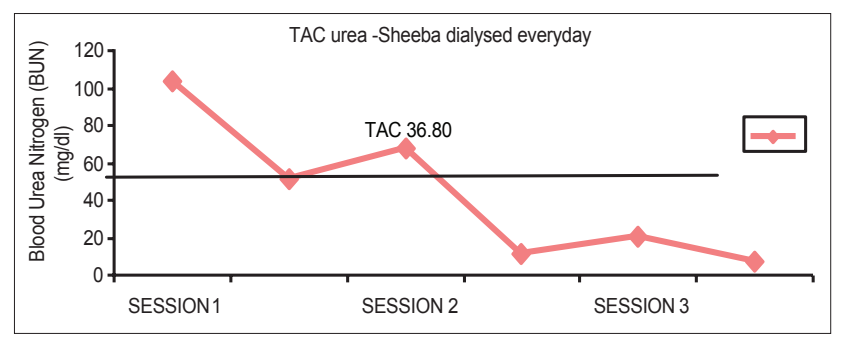

Figure-4: Time avereged concerntration urea - Sheeba dialysed everyday.

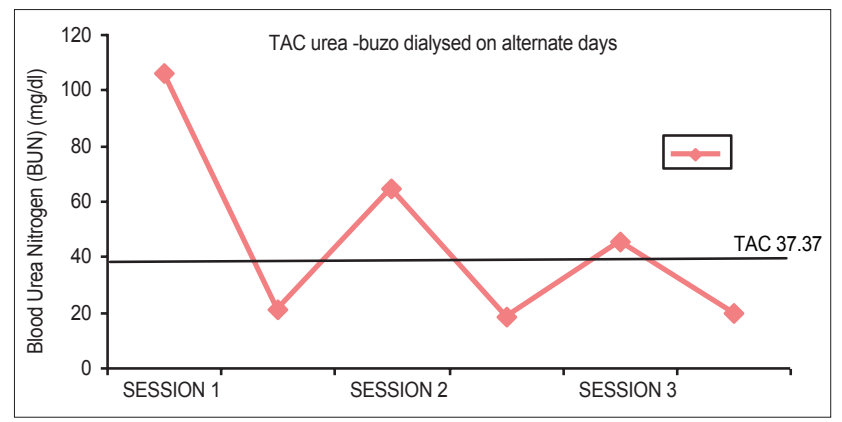

Figure-5: Time avereged concerntration urea - Buzo dialysed on alternate days.

Table-4: TAC - Patients dialysed everyday.

\begin{tabular}{llcccccc}
\hline $\begin{array}{l}\text { Patient } \\
\text { no }\end{array}$ & $\begin{array}{l}\text { Patient } \\
\text { name }\end{array}$ & $\begin{array}{c}\text { Total } \\
\text { sessions }\end{array}$ & $\begin{array}{c}\text { Starting } \\
\text { BUN }\end{array}$ & $\begin{array}{c}\text { Total Td } \\
\text { (h) }\end{array}$ & $\begin{array}{c}\text { Td/session } \\
\text { (h) }\end{array}$ & $\begin{array}{c}\text { Total volume of blood } \\
\text { processed (L/kg) }\end{array}$ & $\begin{array}{c}\text { TAC } \\
\text { (L) }\end{array}$ \\
\hline 1 & Jai & 2 & 138 & 6.25 & 3.12 & 1.17 & 94.79 \\
3 & Sheeba & 2 & 103.3 & 8.3 & 4.17 & 2.79 & 57.93 \\
6 & Pooh & 2 & 81.6 & 5 & 2.5 & 2.22 & 62.6 \\
Mean \pm SD & & & $107.63 \pm 28.45$ & $6.52 \pm 1.67$ & $3 \mathrm{~h} \mathrm{15}$ min \pm 50.4 min & $2.06 \pm 0.82$ & $71.77 \pm 20.07$
\end{tabular}

BUN=Blood Urea Nitrogen, TAC=Time avereged concerntration, $\mathrm{Td}=$ Time of dialysis, SD=Standard deviation

Table-5: TAC - patients dialysed on alternate days.

\begin{tabular}{llcccccc}
\hline $\begin{array}{l}\text { Patient } \\
\text { no }\end{array}$ & $\begin{array}{l}\text { Patient } \\
\text { name }\end{array}$ & $\begin{array}{c}\text { Total } \\
\text { sessions }\end{array}$ & $\begin{array}{c}\text { Starting } \\
\text { BUN }\end{array}$ & $\begin{array}{c}\text { Total Td } \\
\mathbf{( h )}\end{array}$ & $\begin{array}{c}\text { Td/session } \\
\mathbf{( h )}\end{array}$ & $\begin{array}{c}\text { Total volume of blood } \\
\text { processed (L/ } \mathbf{k g})\end{array}$ & $\begin{array}{c}\text { TAC } \\
(\mathbf{m g} / \mathbf{d l})\end{array}$ \\
\hline 1 & Jai & 2 & 112 & 9.5 & 4.75 & 3.91 & 39.50 \\
2 & Tisha & 2 & 104 & 6.4 & 3.2 & 1.88 & 84 \\
5 & Buzo & 2 & 105.96 & 7.16 & 3.58 & 1.93 & 53 \\
8 & Rusty & 2 & 100.92 & 7 & 3.5 & 2.93 & 50.93 \\
Mean \pm SD & & & $105.72 \pm 4.67$ & $7.52 \pm 1.36$ & $3 \mathrm{~h} \mathrm{45} \mathrm{min \pm 40} \mathrm{min}$ & $2.66 \pm 0.96$ & $54.36 \pm 20.33$ \\
\hline
\end{tabular}

$\mathrm{BUN}=$ Blood urea nitrogen, $\mathrm{TAC}=$ Time avereged concerntration, $\mathrm{Td}=$ Time of dialysis, $\mathrm{SD}=$ Standard deviation

Table-6: TAC - patients dialysed everyday versus alternate days (Similar BUN).

\begin{tabular}{|c|c|c|c|c|c|c|c|c|}
\hline \multirow[t]{2}{*}{$\begin{array}{l}\text { Patient } \\
\text { no }\end{array}$} & \multirow[t]{2}{*}{$\begin{array}{l}\text { Patient' } \\
\text { name }\end{array}$} & \multirow[t]{2}{*}{$\begin{array}{c}\text { Total } \\
\text { sessions }\end{array}$} & \multirow[t]{2}{*}{$\begin{array}{l}\text { Starting } \\
\text { BUN }\end{array}$} & \multirow[t]{2}{*}{$\begin{array}{l}\text { Total } \\
\text { Td }(h)\end{array}$} & \multirow[t]{2}{*}{$\begin{array}{c}\text { Td/session } \\
\text { (h) }\end{array}$} & \multicolumn{2}{|c|}{$\begin{array}{l}\text { Total volume of blood } \\
\text { processed }(\mathrm{L} / \mathrm{kg})\end{array}$} & \multirow[t]{2}{*}{$\begin{array}{l}\text { TAC } \\
\mathrm{mg} / \mathrm{dl}\end{array}$} \\
\hline & & & & & & 3 sessions & Per session & \\
\hline \multicolumn{9}{|c|}{ Versus } \\
\hline 2 & Tisha & 3 & 104 & 11.4 & $3 \mathrm{~h} / 48 \mathrm{~min}$ & 3.53 & 1.18 & 45.92 \\
\hline 5 & Buzo & 3 & 105.96 & 11.75 & $3 \mathrm{~h} / 54 \mathrm{~min}$ & 4.12 & 1.37 & 37.37 \\
\hline
\end{tabular}

$\mathrm{BUN}=$ Blood urea nitrogen, $\mathrm{TAC}=$ Time avereged concerntration, $\mathrm{Td}=$ Time of dialysis, $\mathrm{SD}=$ Standard deviation 
patients dialyzed on alternate days (Figures-5 and 6). Thereby concluded stating Alternate day dialysis provides inadequate dialysis dosing in the majority of critically ill-patients. Prolonged dialysis significantly

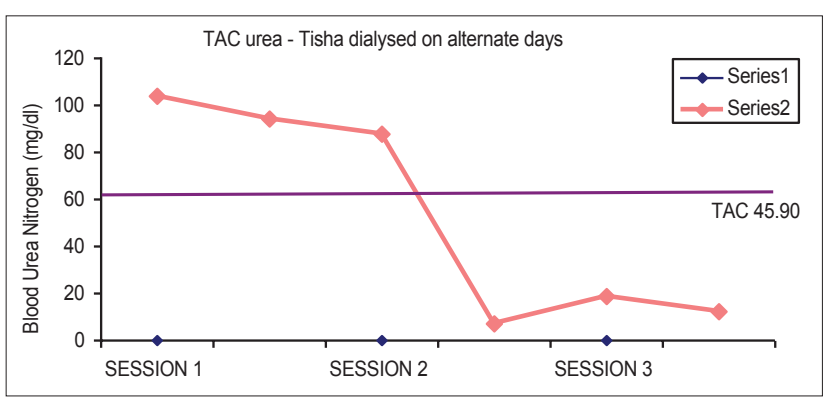

Figure-6: Time avereged concerntration urea - Tisha dialysed on alternate days.

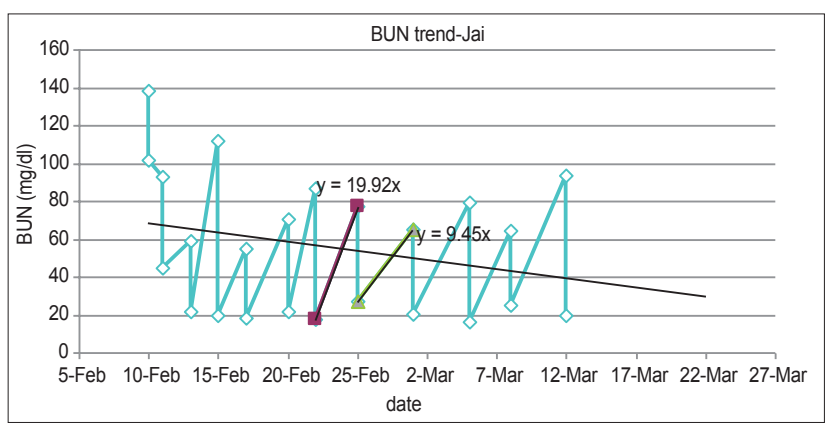

Figure-7: Blood urea nitrogen trend - Jai.

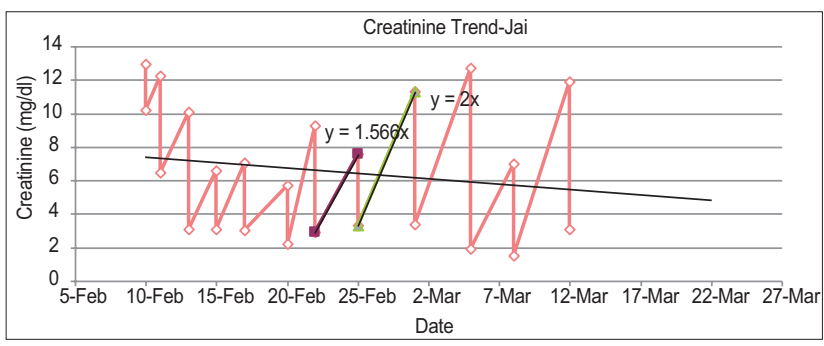

Figure-8: Creatinine trend - Jai. reduces solute concentration levels, especially for those solutes that are distributed in a larger volume. The benefit of frequent hemodialysis may result from improved control of other metabolic by-products, such as phosphate or other retained uremic solutes, more physiologic removal of solutes (yielding lower and less variable time-averaged solute concentrations), or improved control of extracellular volume excess. There exists an inverse correlation between the time and frequency of dialysis and the concentration of uremic retention solutes in the patient, thus increasing both frequency and duration of dialysis results in decreased concentration of uremic retention solutes and thereby reducing the exposure and damage of various organ system due to these toxins [9]. Frequent hemodialysis results in better patient outcomes with respect to owner perceived quality of life for example activity level of their pet, appetite, restoration of normal behavior and activities, amelioration of clinical signs like vomiting, nausea, anorexia. Increasing both dialysis frequency and duration is the superior dialysis schedule [26-29].

Patient Jai was prescribed maintenance dialysis, all the dialysis treatments he underwent were grouped into three groups based on the duration and frequency of the treatment administered as depicted in (Tables-7-9), (Figures-7 and 8). It is clearly evident from the lower TAC urea value of $49.7 \mathrm{mg} / \mathrm{dl}$ of table 8 that more frequent dialysis should be preferred over the conventional thrice weekly concept of dialysis.

\section{Conclusion}

Increasing both dialysis frequency and duration is the superior dialysis schedule. Patient dialyzed everyday with total processed blood volume $1.79 \mathrm{~L} / \mathrm{Kg}$ for $4 \mathrm{~h} 26 \mathrm{~min}$ per session had the lowest TAC of $36.82 \mathrm{mg} / \mathrm{dl}$, thereby was considered as a better prescription.

Table-7: First two sessions (dialysed everyday).

\begin{tabular}{llcccccc}
\hline $\begin{array}{l}\text { Patient } \\
\text { no }\end{array}$ & $\begin{array}{l}\text { Patient } \\
\text { name }\end{array}$ & $\begin{array}{c}\text { Total } \\
\text { sessions }\end{array}$ & $\begin{array}{c}\text { Starting } \\
\text { BUN }\end{array}$ & $\begin{array}{c}\text { Total Td } \\
\text { (h) }\end{array}$ & $\begin{array}{c}\text { Td/session } \\
\mathbf{( h )}\end{array}$ & $\begin{array}{c}\text { Total volume of blood } \\
\text { processed (L/ } \mathbf{k g})\end{array}$ & $\begin{array}{c}\text { TAC } \\
\mathbf{m g} / \mathbf{d l}\end{array}$ \\
\hline 1 & Jai & 2 & 138 & 6.25 & $3 \mathrm{hrs} 7$ mins & 1.17 & 94.79 \\
\hline
\end{tabular}

$\mathrm{BUN}=$ Blood urea nitrogen, $\mathrm{TAC}=$ Time avereged concerntration, $\mathrm{Td}=$ Time of dialysis, $\mathrm{SD}=\mathrm{Standard}$ deviation

Table-8: Third to eighth session ( 6 sessions, 12 days - alt day, less time more frequent).

\begin{tabular}{llcccccc}
\hline $\begin{array}{l}\text { Patient } \\
\text { No }\end{array}$ & $\begin{array}{l}\text { Patient } \\
\text { name }\end{array}$ & $\begin{array}{c}\text { Session } \\
\text { no }\end{array}$ & $\begin{array}{c}\text { Starting } \\
\text { BUN }\end{array}$ & $\begin{array}{c}\text { Total Td } \\
\text { (h) }\end{array}$ & $\begin{array}{c}\text { Td/session } \\
(\mathbf{h})\end{array}$ & $\begin{array}{c}\text { Total volume of blood } \\
\text { processed (L/kg) } \text { per session }\end{array}$ & $\begin{array}{c}\text { TAC } \\
\text { mg/dl }\end{array}$ \\
\hline 1 & Jai & $3-8$ & 59.41 & 28.33 & 4 hrs 43 mins & 1.74 & 49.7 \\
\hline
\end{tabular}

$\mathrm{BUN}=$ Blood urea nitrogen, $\mathrm{TAC}=$ Time avereged concerntration, $\mathrm{Td}=$ Time of dialysis, $\mathrm{SD}=\mathrm{Standard}$ deviation

Table-9: Ninth to twelfth session (4 sessions, 12 days - every third day more lenghthy less frequent).

\begin{tabular}{llcccccc}
\hline $\begin{array}{l}\text { Patient } \\
\text { no }\end{array}$ & $\begin{array}{l}\text { Patient } \\
\text { name }\end{array}$ & $\begin{array}{c}\text { Session } \\
\text { no }\end{array}$ & $\begin{array}{c}\text { Starting } \\
\text { BUN }\end{array}$ & $\begin{array}{c}\text { Total Td } \\
\text { (h) }\end{array}$ & $\begin{array}{c}\text { Td/session } \\
\text { (h) }\end{array}$ & $\begin{array}{c}\text { Total volume of blood } \\
\text { processed (L/ kg) per session }\end{array}$ & $\begin{array}{c}\text { TAC } \\
\text { mg/d }\end{array}$ \\
\hline 1 & Jai & $9-12$ & 64 & 20.91 & 5.2 & 2.77 & 50.56 \\
\hline
\end{tabular}

$\mathrm{BUN}=$ Blood urea nitrogen, $\mathrm{TAC}=$ Time avereged concerntration, $\mathrm{Td}=$ Time of dialysis, $\mathrm{SD}=\mathrm{Standard}$ deviation

Veterinary World, EISSN: 2231-0916 


\section{Author's Contributions}

ET carried out the study and drafted the manuscript, RG guided her through the study.

\section{Acknowledgments}

The authors would like to thank the department of Medicine, Ethics and Jurisprudence, Bombay Veterinary College, for providing the facility to carry out the study. It was a self-funded study.

\section{References}

1. Cowgill, L.D. and Francey, T. (2012) Hemodialysis. In: DiBartola, S.P. editor. Fluid, Electrolyte and AcidBase Disorders in Small Animal Practice. $4^{\text {th }}$ ed. Elsevier Saunders, Philadelphia. p701, 703-704.

2. Cowgill, L.D. and Francey, T. (2006) Hemodialysis. In: DiBartola, S.P. editor. Electrolyte and Acid Base Disorders in Small Animal Practice. $3^{\text {rd }}$ ed. Elsevier Saunders, Philadelphia. p663-700.

3. Cowgill, L.D. and Francey, T. (2006) Hemodialysis. In: DiBartola, S.P. editor. Electrolyte and Acid Base Disorders in Small Animal Practice. $3^{\text {rd }}$ ed. Elsevier Saunders, Philadelphia. p650-677.

4. Brown, S.A. (2007) In: Elliott, J. and Grauer G.F., editors. BSAVA Manual of Canine and Feline Nephrology and Urology. $2^{\text {nd }}$ ed. British Small Animal Veterinary Association, Gloucester, England. p223-230.

5. Polzin, D.J. (2011) In: Chronic Kidney Disease Nephrology and Urology of Small Animals. Wiley-Blackwell, Ames, IA. p433-471.

6. Gross M., Maierhofer, A., Tetta, C., Lsenecal and Canaud, B. (2007) Online clearance measurement in high-efficiency hemodiafiltration. Kidney Int., 72(12): 1550-1553.

7. Langston, C.E. (2012) Hemodialysis. In: DiBartola, S.P. editor. Fluid, Electrolyte and Acid-Base Disorders in Small Animal Practice. $4^{\text {th }}$ ed. Elsevier Saunders, Philadelphia. p703-708.

8. Daugirdas, J.T. (2007) Physiologic principles and urea kinetic modelling. In: Daugirdas John, T., Blake, P.G. and Ing, T.S. editors. Handbook of Dialysis. $4^{\text {th }}$ ed. Lippincott Williams \& Wilkins, Philadelphia, USA. p25-58.

9. Daugirdas, J.T. and Tattersall, J. (2010) Effect of treatment spacing and frequency on three measures of equivalent clearance, including standard Kt/V. Nephrol. Dial. Transplant., 25(2): 558-61.

10. Gotch, F.A., Panlilio, F.M. and Buyaki, R.A. (2004) Mechanisms determining the ratioof conductivity clearance to urea clearance. Kidney Int. Suppl., 89: 23-24.

11. Greene T., Daugirdas, J.T., Depner, T.A., Gotch F. and Kuhlman, M. (2009) Solute clearances and fluid removal in the frequent hemodialysis network trials. Am. J. Kidney. Dis., 53(5): 835-844.

12. Jeffrey, P. and Christopher, T.C. (2009) Home hemodialysis, daily hemodialysis, and nocturnal hemodialysis: Core curriculum. Am. J. Kidney Dis., 54(6): 1171-84.

13. Segev, G., Kass, P.H. and Francey, T. (2008) A novel clinical scoring system for outcome prediction in dogs with acute kidney injury managed by hemodialysis. J. Vet. Intern. Med., 22(2): 301-308.

14. Serge, C., Cathy, E.L. and Karen, P. (2011) Vascular access for extracorporeal renal replacement therapy in veterinary medicine. Vet. Clin. North Am. Small, 41(1): 147-161.

15. Cowgill, L.D. (2011) Urea kinetics and intermittent dialysis prescription in small animals. Vet. Clin. North Am. Small, 41(1): 193-225.

16. Lowrie, E and Lew, N. (1991) The urea reduction ratio (URR): A simple method for evaluating hemodialysis treatment. Contemp. Dial Nephrol. 12: 11-20.

17. Sheri, R. (2011) Anticoagulation in intermittent hemodialysis: Pathways, protocols, and pitfalls. Vet. Clin. North Am. Small, 41(1): 163-175.

18. Bartges, J. and Polzin, D.J. (2011) Nephrology and Urology of Small Animals. $1^{\text {st }}$ ed. Ames, Iowa, Blackwell Publishing Ltd., p440-445.

19. Grauer, V.G.F. (2000) Effects of enalapril versus placebo as a treatment for canine idiopathic glomerulonephritis. J. Vet. Intern. Med., 14(5): 526-533.

20. Tvedten, H. (2010) Schalm's Veterinary Hematology. $6^{\text {th }}$ ed. Backwell Publishing Ltd., Ames, IA. p152-161.

21. IRIS Guidlines 2009 Staging of CKD. In CKD staging guidelines of IRIS: $1-10$.

22. Polzin, D.J. (2010) Chronic kidney direase. In: Ettinger, S.J., Feldman, E.C., editors. Textbook of Veterinary Internal Medicine. Vol. 2. Saunders Elsevier, St Louis, MO. p1990-2021.

23. Lopot, F.V. (1988) Time averaged concentration-time averaged deviation: A new concept in mathematical assessment of dialysis adequacy. Nephrol. Dial Transplant., 3(6): 846-848.

24. Hemodialysis Adequacy 2006 Work Group. Clinical practice guidelines for hemodialysis adequacy, update 2006. Am. J. Kidney Dis., 2006;48 Suppl 1: S2S-90.

25. Suri, R.S., Depner, T. and Lindsay, R.M. (2004) Dialysis prescription and dose monitoring in frequent hemodialysis. Contrib. Nephrol., 145: 75-88.

26. Daugirdas, J.T., Hanna, M.G., Becker-Cohen R. and Langman, C.B. (2010) Dose of dialysis based on body surface area is markedly less in younger children than in older adolescents. Clin. J. Am. Soc. Nephrol., 5: 821-827.

27. Depner, T.A. (2005) Hemodialysis adequacy: Basic essentials and practical points for nephrologist in training. Hemodial. Int., 9(3): 241-254.

28. Francesca, T., Jinyao, Z., Li, Y., Angelo, K., Peter, K., Rajiv, S., Juergen, B., Friedrich P., Takashi, A., Ronald, P. and Bruce, R. (2012) Longer dialysis session length is associated with better intermediate outcomes and survival among patients on in-center three times per week hemodialysis: results from the dialysis outcomes and practice patterns study (DOPPS). Nephrol. Dial Transplant., 10: 21.

29. Sunny, E., Wim, V. B., Annemieke, D., Smet, R., Bart, M., Paul De Deyn, P., Pascal, V. and Raymond, V. (2009) Impact of increasing haemodialysis frequency versus haemodialysis duration on removal of urea and guanidino compounds: A kinetic analysis Nephrol. Dial Transplant., 24: $2225-2232$. 